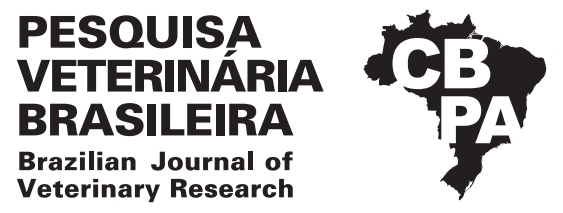

Pesq. Vet. Bras. 38(7):1423-1430, julho 2018 DOI: 10.1590/1678-5150-PVB-5222

Original Article

ISSN 0100-736X (Print)

ISSN 1678-5150 (Online)

\title{
Anesthetic complications in diabetic dogs subjected to phacoemulsification $^{1}$
}

\author{
Paula F. Pacheco ${ }^{2 *}$, Viviane S. Galeazzi², Geni C.F. Patrício², Patrícia B. Flôr², \\ Angélica V. Safatle ${ }^{2}$ and Silvia R.G. Cortopassi ${ }^{2}$
}

\begin{abstract}
Pacheco P.F., Galeazzi V.S., Patrício G.C.F., Flôr P.B., Safatle A.V. \& Cortopassi S.R.G. 2018. Anesthetic complications in diabetic dogs subjected to phacoemulsification. Complicações anestésicas em cães diabéticos submetidos a facoemulsificação. Pesquisa Veterinária Brasileira 38(7):1423-1430. Departamento de Cirurgia, Faculdade de Medicina Veterinária e Zooctenia, Universidade de São Paulo, Avenida Prof. Dr. Orlando Marques de Paiva 87, São Paulo, SP 05508-270, Brazil. E-mail: paulafink@usp.br

The aim of this paper was to compare the incidence of anesthetic complications in diabetic and nondiabetic dogs subjected to phacoemulsification. In total, 30 male and female dogs of different breeds were used. The dogs were distributed into two groups: diabetic (DG) (n=15) and control (CG) $(\mathrm{n}=15)$. The animals were premedicated with acepromazine $(0.03 \mathrm{mg} / \mathrm{kg})$ and meperidine $(4 \mathrm{mg} / \mathrm{kg})$, intramuscularly. After 20 minutes, anesthesia was induced with propofol $(2$ to $5 \mathrm{mg} / \mathrm{kg}$ ) and maintained with isoflurane. The animals were monitored and the heart rate, respiratory rate, peripheral oxyhemoglobin saturation, end tidal carbon dioxide tension, inspired and expired isoflurane fraction, and invasive arterial pressure were recorded at 10 minute intervals during the surgical procedure. Arterial hemogasometry was performed after anesthetic induction (T0) and at the end of the surgical procedure. Diabetic patients (DG $10 \pm 2$ years) were older than non-diabetic group (CG $6 \pm 2$ years). The expired isoflurane fraction after induction was $30 \%$ higher in the control group (CG $1.3 \pm 0.3 \%$, DG $1.0 \pm 0.2 \%)(\mathrm{p}<0.01)$. The most common anesthetic complication was hypotension. In total, $80 \%$ of the diabetic animals $(n=12)$ exhibited mean arterial pressure (MAP) lower than $60 \mathrm{mmHg}(54 \pm 9.6 \mathrm{mmHg})$ after anesthetic induction, and $83 \%$ of the hypotensive dogs $(n=10)$ required vasoactive drugs to treat hypotension. Regarding hemodynamic changes, diabetic patients subjected to general anesthesia were more likely to exhibit hypotension which may be due to the response of older animals to the drugs used; however, this change deserves further investigation.
\end{abstract}

INDEX TERMS: Anesthetic complications, diabetes, dogs, phacoemulsification, anesthesia, dog, diabetes mellitus, hypotension.

RESUMO. - [Complicações anestésicas em cães diabéticos submetidos a facoemulsificação.] 0 objetivo do presente estudo foi comparar a incidência de complicações anestésicas em cães diabéticos e não diabéticos submetidos a cirurgia de facoemulsificação. Foram utilizados 30 cães, machos ou fêmeas de diversas raças. Os cães foram distribuídos em dois grupos: diabético (GD) (n=15) e controle (GC) ( $\mathrm{n}=15)$. Os animais foram pré-tratados com acepromazina $(0,03 \mathrm{mg} / \mathrm{kg})$ e meperidina $(4 \mathrm{mg} / \mathrm{kg})$, pela via intramuscular. Após 20 minutos, a indução

\footnotetext{
${ }^{1}$ Received on January 15, 2017.

Accepted for publication on June 21, 2017.

${ }^{2}$ Departamento de Cirurgia, Faculdade de Medicina Veterinária e Zootecnia, Universidade de São Paulo, Avenida Prof. Dr. Orlando Marques de Paiva 87, São Paulo, SP 05508-270, Brazil. *Corresponding author: paulafink@usp.br
}

foi realizada com propofol ( 2 a $5 \mathrm{mg} / \mathrm{kg}$ ) e a manutenção da anestesia com isofluorano. Os animais foram monitorados e as variáveis de frequência cardíaca, frequência respiratória, saturação oxihemoglobina periférica, concentração dióxido de carbono no final da expiração, fração inspirada e expirada de isofluorano e pressão arterial invasiva, foram registradas em intervalos de 10 minutos durante o procedimento cirúrgico. A hemogasometria arterial foi realizada após a indução (T0) e ao final do procedimento cirúrgico (T40). A idade dos animais do grupo diabético ( $10 \pm 2$ anos) foi superior em relação aos animais do grupo controle $(6 \pm 2$ anos $)(p<0,0001)$. A concentração expirada de isofluorano após a indução foi $30 \%$ superior nos animais do grupo controle (GC 1,3 $\pm 0,3 \%$, GD 1,0 $\pm 0,2 \%$ ) $(\mathrm{p}<0,01)$. A complicação anestésica mais comum foi a hipotensão 
arterial, 80\% dos animais diabéticos $(\mathrm{n}=12)$ apresentaram pressão arterial média inferior a $60 \mathrm{mmHg}(54 \pm 9.6 \mathrm{mmHg})$ após indução anestésica; 83\% dos cães hipotensos $(\mathrm{n}=10)$ necessitaram de fármacos vasoativos para tratamento da hipotensão. Com relação às alterações hemodinâmicas, os pacientes diabéticos submetidos à anestesia geral foram mais propensos à hipotensão arterial que pode ser decorrente da resposta dos animais mais velhos aos fármacos empregados; entretanto essa alteração merece maior investigação.

TERMOS DE INDEXAÇÃO: Complicação anestésica, cães, diabetes, facoemulsificação, anestesia, hipotensão.

\section{INTRODUCTION}

Diabetes mellitus (DM) is a common endocrine disease in dogs and is characterized by persistent hyperglycemia resulting from insulin secretion deficiency (Feldman \& Nelson 2004). Cataracts are a common complication in diabetic dogs and usually exhibit fast and bilateral development and appear to be related to glycemic control (Plummer et al. 2007). Approximately $75 \%$ of diabetic dogs develop cataracts within 1 year of diagnosis (Beam et al. 1999). Phacoemulsification is the most commonly recommended procedure for the treatment of cataracts (Plummer et al. 2007).

Most diabetic animals are on average 9 years old or more and have associated endocrine diseases, obesity, and poorly controlled diabetes (Feldman \& Nelson 2004). Patients usually present with hypo- or hyperglycemia and require treatment prior to the anesthetic procedure (Kronen et al. 2001). It is recommended that the total or partial dose of insulin used daily by patients is administered subcutaneously on the morning of the day of surgery for perioperative glycemic control (Kronen et al. 2001).

In human medicine, there are reports of hemodynamic instability during anesthetic induction and maintenance in diabetic patients (Latson et al. 1994, Kronen et al. 2001). Although there are few published studies in veterinary medicine, hypotension and bradycardia were the most commonly described occurrences associated with anesthesia of diabetic dogs subjected to phacoemulsification surgery (Oliver et al. 2010). This study aimed to evaluate anesthetic complications in diabetic and nondiabetic dogs subjected to phacoemulsification surgery.

\section{MATERIALS AND METHODS}

In total, 30 male and female dogs of different breeds were treated by the Ophthalmology Service of the Surgery Department of the School of Veterinary Medicine of the University of São Paulo (Universidade de São Paulo - USP) from January 2012 to July 2013. The animals of DG and CG presented, respectively, $10 \pm 2$ and $6 \pm 2$ years. The body weight of DG was $19.77 \pm 12.3$ and CG $7.07 \pm 4.1 \mathrm{~kg}$. Informed consent was obtained from the owners of all dogs included in the study. The experimental design was approved by the Ethics Committee on Animal use under protocol no. 2514/2011. All dogs underwent unilateral phacoemulsification; the procedures were performed by the same surgeon and lasted 40 to 50 minutes. Among the selected animals randomly, 15 did not have diabetes mellitus and were considered clinically healthy (Control Group - CG), and 15 exhibited compensated diabetes mellitus (Diabetes Group - DG). All animals were previously submitted to clinical and laboratory examination by the Clinical Service, School of Veterinary Medicine and Animal Science, University of São Paulo before the surgical procedure. Animals with other endocrine and cardiac diseases that required drug intervention (diuretics, vasodilators, inotropes) were excluded from the study.

Before surgery, all animals were deprived of food for 8 hours and of water for 2 hours. The subcutaneous administration of one third of the typical NPH (Neutral Protamine Hagedorn; Lilly, São Paulo, Brazil) insulin dose before surgery was recommended to all diabetic dogs. The animals underwent preoperative laboratory and cardiac tests: complete blood count, kidney and liver profile (urea, creatinine, albumin, total protein, alanine aminotransferase, aspartate aminotransferase), triglycerides, cholesterol, fructosamine, and electrocardiogram. The anesthetic procedure was initiated with the administration of pre-anesthetic medication with acepromazine $0.03 \mathrm{mg} / \mathrm{kg}$ (Acepran ${ }^{\mathrm{TM}}$, Univet, São Paulo, Brazil) and meperidine $4 \mathrm{mg} / \mathrm{kg}$ (Petidina ${ }^{\mathrm{TM}}$, Cristália, São Paulo, Brazil) intramuscularly. The anesthesia was induced with propofol (Propovan ${ }^{\mathrm{TM}}$, Cristália, São Paulo/SP, Brazil) intravenously ( 2 to $5 \mathrm{mg} / \mathrm{kg}$ ). After endotracheal intubation, the animals received isoflurane (Isoforine ${ }^{\mathrm{TM}}$, Abbott, São Paulo/SP, Brazil) in 100\% oxygen by a rebreathing circuit. Before surgery, the neuromuscular blockade was performed with rocuronium $0.6 \mathrm{mg} / \mathrm{kg}$ i.v. (Rocuron ${ }^{\mathrm{TM}}$, Cristália, São Paulo/SP, Brazil). All animals were mechanically ventilated during surgery (pressure-controlled 8 to $12 \mathrm{~cm} \mathrm{H}_{2} \mathrm{O}$ mechanical ventilation was instituted and respiratory rate maintained between 10 and 14 movements per minute). Fluid therapy was performed with $0.9 \%$ saline at a volume of $5 \mathrm{~mL} / \mathrm{kg} / \mathrm{h}$. At the end of the surgical procedure, the animals received dipyrone $25 \mathrm{mg} / \mathrm{kg}$ (D-500 ${ }^{\mathrm{TM}}$, Fort Dodge, São Paulo/SP, Brazil), tramadol hydrochloride $2 \mathrm{mg} / \mathrm{kg}$ (Tramadon ${ }^{\mathrm{T}}$, Cristália, São Paulo/SP, Brazil) and meloxicam $0.2 \mathrm{mg} / \mathrm{kg}$ (Maxicam $^{\text {TM }}$, OuroFino, Cravinhos/SP, Brazil) intravenously for analgesic control.

The analgesic rescue during the perioperative period was performed with $5 \mu \mathrm{g} / \mathrm{kg}$ of fentanyl (Fentanest ${ }^{\mathrm{TM}}$, Cristália, São Paulo/SP, Brazil) intravenously when patients experienced rise in heart rate and mean arterial pressure of $20 \%$ from values demonstrated at the initial moment (T0).

During the perioperative period, the blood glucose was measured using a portable glucosimeter (OptiumXceed ${ }^{\odot}$, Abott, São Paulo/SP, Brazil) at 5 time-points: before the pre-anesthetic medication, 15 minutes after the pre-anesthetic medication, after anesthesia induction, at the end of the surgical procedure during capsulorhexis, and immediately before hospital discharge.

After adequate anesthesia was established, the animals underwent arterial catheterization of metatarsal artery to perform hemogasometric $\left(\mathrm{pH}, \mathrm{HCO}_{3}, \mathrm{BE}, \mathrm{AG}\right)$ and invasive arterial pressure measurements (Invasive Blood Pressure Transducer - BD ${ }^{\odot}$, New Jersey - USA).

The physiological parameters were monitored and recorded in 10-minute intervals. A multiparametric monitor (Dash $4000^{\circ}, \mathrm{GE}$ Healthcare, São Paulo, Brazil) was used to analyze the heart rate (HR) and rhythm, respiratory rate (RR), peripheral oxyhemoglobin saturation $\left(\mathrm{SpO}_{2}\right)$, invasive arterial pressure (PAI), and esophageal temperature. End tidal carbon dioxide tension $\left(\mathrm{ETCO}_{2}\right)$ and the inspired and expired isoflurane fractions were obtained using a gas analyzer (Poet IQ2 ${ }^{\odot}$, Criticare, Wisconsin, USA). End tidal carbon dioxide tension was maintained at $35-45 \mathrm{mmHg}$.

Five minutes after the induction of anesthesia was considered the initial time (T0) and the parameters were recorded in 10-minute intervals. Because the surgical procedures lasted between 40 and 50 minutes, we statistically analyzed the values obtained up to minute 40 (T40).

The following conditions were considered anesthetic complications: bradycardia (heart rate below $60 \mathrm{bpm}$ associated with hypotension), hypotension (mean arterial pressure (MAP) below $55 \mathrm{mmHg}$ ), cardiac arrhythmias, hypoglycemia, or severe hyperglycemia (Table 1).

Hypotension was treated by reducing the administration of general anesthetic and by giving a bolus $0.9 \%$ saline solution IV (20 ml/kg for 15 minutes). If the hypotension persisted, the dogs were 
treated with a bolus $0.3 \mathrm{mg} / \mathrm{kg}$ of ephedrine IV (Efedrin ${ }^{\mathrm{TM}}$, Cristália, São Paulo/SP, Brazil) and/or norepinephrine at $0.01 \mu \mathrm{g} / \mathrm{kg} / \mathrm{min}$ IV (Norepinefrina $^{\mathrm{TM}}$, Hipolabor, Minas Gerais, Brazil). The animals with bradycardia received $0.03 \mathrm{mg} / \mathrm{kg}$ atropine (Hytropin ${ }^{\mathrm{TM}}$, Hypofarma, Minas Gerais, Brazil) intravenously.

Animals with hypoglycemia (blood glucose levels below 70mg/dL) received $1 \mathrm{~mL} / \mathrm{kg}$ of $25 \%$ glucose diluted $(10 \mathrm{ml})$ and slowly administered intravenously followed by infusion of $5 \%$ glucose $(3 \mathrm{~mL} / \mathrm{kg} / \mathrm{h})$ untilblood glucose levels were normalized. Animals considered hyperglycemic (blood glucose levels above $300 \mathrm{mg} / \mathrm{dL}$ ) received regular insulin $(0.12 \mathrm{U} / \mathrm{kg})$ intramuscularly followed by $0.9 \%$ saline infusion intravenously ( $3 \mathrm{~mL} / \mathrm{kg} /$ hour).

Statistical analysis. Comparisons of variables between the CG (Control Group) and the DG (Diabetes Group) for each time-point were analyzed by the unpaired Student's t test (for parametric data) or by the Mann-Whitney test (for nonparametric data). To evaluate variables at different time-points in each Group (Control or Diabetic), 1-way repeated measures ANOVA was performed, followed by Bonferroni post-hoc test. In the plots, data were expressed as the mean \pm standard deviation. Differences were considered significant when $\mathrm{p}<0.05$. The following notation was used in figures: $\left({ }^{*}\right)$ when $\mathrm{p}$ between $<0.05$ and $>0.01$; $\left({ }^{* *}\right)$ when $\mathrm{p} \leq 0.01$ and $>0.001 ;\left({ }^{* * *}\right)$ when $\mathrm{p} \leq 0.001$ and $>0.0001$.

\section{RESULTS}

A total of 30 dogs from different breeds were evaluated, including 20 females $(\mathrm{CG}=10 ; \mathrm{DG}=10)$ and 10 males $(\mathrm{CG}=5$; $D G=5$ ). There was no difference between the number of males and females on each group. Animals from the DG were older (10.27 \pm 2.1 years) compared with the CG $(6.27 \pm 2.2$ years $)$, and the difference was significant $(\mathrm{p}<0.0001)$. Similarly, the body weight of diabetic dogs $(19.77 \pm 12.3 \mathrm{~kg})$ was higher than the animals from the CG $(7.07 \pm 4.1 \mathrm{~kg})(\mathrm{p}<0.0007)$.

The mean blood glucose levels at baseline were similar in both groups; seven animals from the DG received 1/3 of the
$\mathrm{NPH}$ insulin dose subcutaneously in the morning at fasting according to the recommendations, including 2 animals with severe hypoglycemia (values lower than $50 \mathrm{mg} / \mathrm{dL}$ ). Only 1 diabetic dog had hypoglycemia without previous insulin administration. At the remaining time-points, animals from the DG exhibited higher blood glucose levels when compared with animals from the CG $(\mathrm{p}<0.01)$ (Fig.1). Animals from the DG exhibited higher fructosamine and cholesterol levels compared with the $\mathrm{CG}$, and the difference was significant $(p<0.0001)$. There was no significant difference in triglyceride levels between the groups.

Regarding the variables analyzed in the trans-anesthetic period, the heart rate values did not differ between the groups at any of the time-points (Table 2). In the control group, 5 animals (33\%) received fentanyl during surgery, while in the DG only $2(13 \%)$ required the drug. There was no correlation between

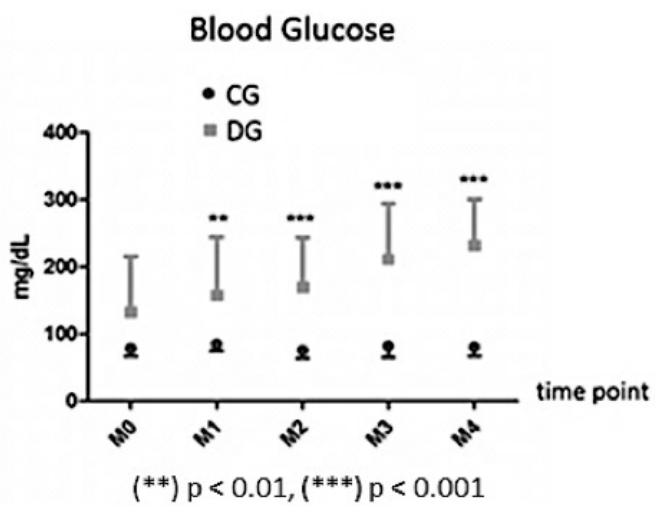

Fig.1. Graphical representation of mean and standard deviation values of blood glucose levels $(\mathrm{mg} / \mathrm{dL}$ ) of animals from the control group (CG) and the diabetic group (DG) at different time-points.

Table 1. Anesthetic complications

\begin{tabular}{|c|c|c|c|}
\hline Complication & Criterion & Unit & Reference \\
\hline Bradycardia & HR $<60$ (associated with hypotension) & bpm & Haskins 2003 \\
\hline Hypotension & MAP $\leq 55$ & $\mathrm{mmHg}$ & Tanifuji \& Eger 1976 \\
\hline Hypoglycemia & Blood glucose $<70$ & $\mathrm{mg} / \mathrm{dL}$ & Kronen et al. 2001 \\
\hline Hyperglycemia & Blood glucose $>300$ & $\mathrm{mg} / \mathrm{dL}$ & Kronen et al. 2001 \\
\hline
\end{tabular}

$\overline{\mathrm{MAP}}=$ mean arterial pressure, $\mathrm{HR}=$ heart rate, $\mathrm{bpm}=$ beats per minute. Adapted from Oliver et al. 2010.

Table 2. Mean and respective standard deviation values of the heart rate (bpm), systolic arterial pressure (mmHg), mean arterial pressure $(\mathrm{mmHg})$, and diastolic arterial pressure $(\mathrm{mmHg})$ measured by the direct method during anesthesia in the control group (CG) and in the diabetic group (DG)

\begin{tabular}{|c|c|c|c|c|c|c|}
\hline \multicolumn{7}{|c|}{ Time-Points } \\
\hline Variables & Group & Induction (T0) & $10 \min (\mathrm{T} 10)$ & $20 \min (\mathrm{T} 20)$ & $30 \min (\mathrm{T} 30)$ & $40 \min (\mathrm{T} 40)$ \\
\hline \multirow[t]{2}{*}{ HR (bpm) } & CG & $96 \pm 21$ & $86 \pm 22$ & $94 \pm 25$ & $103 \pm 24$ & $97 \pm 19$ \\
\hline & DG & $82 \pm 20$ & $83 \pm 18$ & $79 \pm 15$ & $94 \pm 37$ & $90 \pm 18$ \\
\hline \multirow[t]{2}{*}{ SAP } & CG & $100 \pm 17.3$ & $92 \pm 18.2$ & $90 \pm 14.5$ & $89 \pm 16.3$ & $96 \pm 9.6$ \\
\hline & $\mathrm{DG}$ & $86 \pm 17.6$ & $87 \pm 14.8$ & $97 \pm 40.8$ & $97 \pm 31.2$ & $97 \pm 18.1$ \\
\hline \multirow[t]{2}{*}{ MAP } & CG & $70 \pm 12.5$ & $63 \pm 10$ & $65 \pm 9.2$ & $62 \pm 7.1$ & $68 \pm 6.2$ \\
\hline & DG & $54 \pm 9.6$ & $56 \pm 8.8$ & $63 \pm 24.3$ & $63 \pm 22.2$ & $64 \pm 8.2$ \\
\hline \multirow[t]{2}{*}{ DAP } & $\mathrm{CG}$ & $55 \pm 9.5$ & $49 \pm 7.8$ & $52 \pm 9.9$ & $49 \pm 5.6$ & $53 \pm 7.5$ \\
\hline & DG & $43 \pm 7.9$ & $44 \pm 8.7$ & $48 \pm 18.0$ & $50 \pm 20.1$ & $50 \pm 8.0$ \\
\hline
\end{tabular}

$\overline{\mathrm{HR}}=$ heart rate, $\mathrm{bpm}=$ beats per minute, $\mathrm{SAP}=$ systolic arterial pressure, $\mathrm{MAP}=$ mean arterial pressure, $\mathrm{DAP}=$ diastolic arterial pressure. 
the administration of fentanyl and episodes of bradycardia in these animals. Two animals in the CG and 4 animals in the DG received $0.03 \mathrm{mg} / \mathrm{kg}$ of atropine intravenously to treat bradycardia. The dose of propofol used in induction was 30\% lower in diabetic animals. The respiratory rate analysis showed that this variable was lower in diabetic animals compared with the control group at the anesthetic induction time (T0) (DG $10 \pm 1$ breaths per min.; CG 14 $\pm 9 \mathrm{bpm})(\mathrm{p}<0.01)$ and after 10 minutes (T10) (DG 11 \pm 2 bpm; CG 12 $\pm 2 b p m)(p<0.05)$ (Table 3 ). The $\mathrm{SpO}_{2}$ and $\mathrm{ETCO}_{2}$ values did not vary between the groups or between the time-points evaluated (Table 3).

Mean $\mathrm{pH}$ values did not differ significantly between groups throughout the evaluated moments (T0 - CG 7.32 \pm 0.04 ,

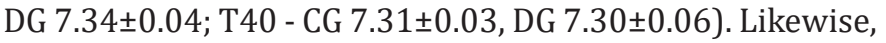
the $\mathrm{HCO}_{3}$ and $\mathrm{BE}$ values showed no difference between the same groups (T0 - CG 20.0 \pm 1.5 , DG 18.5 \pm 2.0 ; T40- CG 20.0 \pm 1.3 , DG 18.5 \pm 2.0 ) (T0 - CG $-5.2 \pm 1.8$, DG $-5.8 \pm 1.8$; T40 - CG -5.7 \pm 1.2 , DG $-7.2 \pm 2.0$, respectively) (Table 4 ).

The expired isoflurane fraction was lower in diabetic patients after the anesthetic induction (T0) (DG 1.0 $\pm 0.2 \%$; CG 1.3 $\pm 0.3 \%$ ) $(\mathrm{p}<0.01)$ and at 30 minutes (T30) (DG 1.1 $\pm 0.2 \%$; CG $1.3 \pm 0.2 \%$ ) $(\mathrm{p}<0.001)$ compared with the CG (Table 3).

The systolic arterial pressure (SAP) was lower in animals from the DG compared with animals from the CG after the anesthetic induction (T0) (DG) 86 $\pm 17.6 \mathrm{mmHg}$; CG 100 $\pm 17.3 \mathrm{mmHg}$ ) $(\mathrm{p}<0.05)$ (Fig.2) (Table 2). Similarly to the systolic arterial pressure, the mean arterial pressure of diabetic dogs was lower at T0 (DG 54 $\pm 9.6 \mathrm{mmHg}$; CG 70 $\pm 12.5 \mathrm{mmHg})(\mathrm{p}<0.05)$ (Table 2); $80 \%$ of diabetic patients $(n=12)$ and $33 \%$ of patients from the control groups $(n=5)$ exhibited MAP lower than 60 $\mathrm{mmHg}$ immediately after the anesthetic induction(T0) (Fig.3). Dogs from the DG exhibited lower diastolic arterial pressure values compared with those from the CG after the anesthetic induction (T0) (DG 43 $\pm 7.9 \mathrm{mmHg}$; CG 55 $\pm 9.5 \mathrm{mmHg})(\mathrm{p}<0.01)$ (Fig.4) (Table 2).

Even after the decrease in the inspired isoflurane concentration and the bolus administration of saline, 10 diabetic animals exhibited MAP $\leq 55 \mathrm{mmHg}$. Ephedrine was administered $(0.3 \mathrm{mg} / \mathrm{kg})$ intravenously in four diabetic dogs, and only two responded satisfactorily; four diabetic dogs received norepinephrine $(0.1 \mu \mathrm{g} / \mathrm{kg} / \mathrm{min})$ and exhibited increased arterial pressure. Two animals demonstrated reflex bradycardia due to the significant increase in arterial pressure after norepinephrine infusion. Two diabetic animals exhibited hypotension associated with bradycardia, and the arterial pressure improved after intravenous administration of atropine $(0.03 \mathrm{mg} / \mathrm{kg})$.

Table 3. Mean and standard deviation values of the respiratory rate $(\mathrm{bpm})$, end-tidal $\mathrm{CO}_{2}$ concentration (\%), oxygen saturation (\%), inspired isoflurane concentration (\%), and expired isoflurane concentration (\%) during anesthesia in the control group (CG) and in the diabetic group (DG)

\begin{tabular}{|c|c|c|c|c|c|c|}
\hline \multicolumn{7}{|c|}{ Time-Points } \\
\hline Variables & Group & Induction (T0) & $10 \min (\mathrm{T} 10)$ & $20 \min (\mathrm{T} 20)$ & $30 \min (\mathrm{T} 30)$ & $40 \min (\mathrm{T} 40)$ \\
\hline \multirow[t]{2}{*}{$\mathrm{RR}$} & CG & $14 \pm 9$ & $12 \pm 2$ & $12 \pm 2$ & $12 \pm 2$ & $12 \pm 2$ \\
\hline & DG & $10 \pm 1$ & $11 \pm 2$ & $11 \pm 2$ & $11 \pm 4$ & $12 \pm 3$ \\
\hline $\mathrm{ETCO}_{2}$ & DG & $34.9 \pm 3.6$ & $34.4 \pm 4.1$ & $34.5 \pm 4.4$ & $36.3 \pm 7.3$ & $35.0 \pm 5.7$ \\
\hline $\mathrm{SaO}_{2}$ & CG & $98.4 \pm 1.0$ & $98.6 \pm 0.8$ & $98.5 \pm 0.9$ & $99.0 \pm 1.0$ & $98.9 \pm 0.8$ \\
\hline Iso ins & DG & $1.6 \pm 0.3$ & $1.7 \pm 0.4$ & $1.6 \pm 0.4$ & $1.6 \pm 0.5$ & $1.6 \pm 0.3$ \\
\hline \multirow[t]{2}{*}{ Iso exp } & $\mathrm{CG}$ & $1.3 \pm 0.3$ & $1.3 \pm 0.3$ & $1.3 \pm 0.2$ & $1.3 \pm 0.2$ & $1.2 \pm 0.2$ \\
\hline & DG & $1.0 \pm 0.2$ & $1.2 \pm 0.2$ & $1.2 \pm 0.2$ & $1.1 \pm 0.2$ & $1.1 \pm 0.2$ \\
\hline
\end{tabular}

$\mathrm{RR}=$ respiratory rate, $\mathrm{ETCO}_{2}=$ end-tidal $\mathrm{CO}_{2}$ concentration, $\mathrm{SaO}_{2}=$ oxygen saturation, Iso ins = inspired isoflurane concentration, Iso exp = expired isoflurane concentration.

Table 4. Mean and standard deviation values of the $\mathrm{pH}$ (hydrogenionic potential), bicarbonate $\left(\mathrm{HCO}_{3}^{-}\right)$, base-excess $\left(\mathrm{BE}^{-}\right)$and anion gap (AG) during anesthesia in the control group (CG) and in the diabetic group (DG)

\begin{tabular}{|c|c|c|c|}
\hline \multicolumn{4}{|c|}{ Time - Points } \\
\hline Variables & Group & Induction (T0) & $40 \min (\mathrm{T} 40)$ \\
\hline $\mathrm{pH}$ & DG & $7.34 \pm 0.04$ & $7,30 \pm 0.06$ \\
\hline $\mathrm{HCO}_{3}^{-}$ & DG & $18.5 \pm 2.0$ & $18.5 \pm 1.9$ \\
\hline $\mathrm{BE}$ & $\mathrm{CG}$ & $-5.2 \pm 1.8$ & $-5.7 \pm 1.2$ \\
\hline $\mathrm{AG}$ & DG & $20 \pm 2.3$ & $20 \pm 4.0$ \\
\hline
\end{tabular}

$\overline{\mathrm{pH}}=$ hydrogenionic potential, $\mathrm{HCO}_{3}{ }^{-}=$bicarbonate $(\mathrm{mEq} / \mathrm{L}), \mathrm{BE}=$ base-excess, $\mathrm{AG}=$ anion gap. 


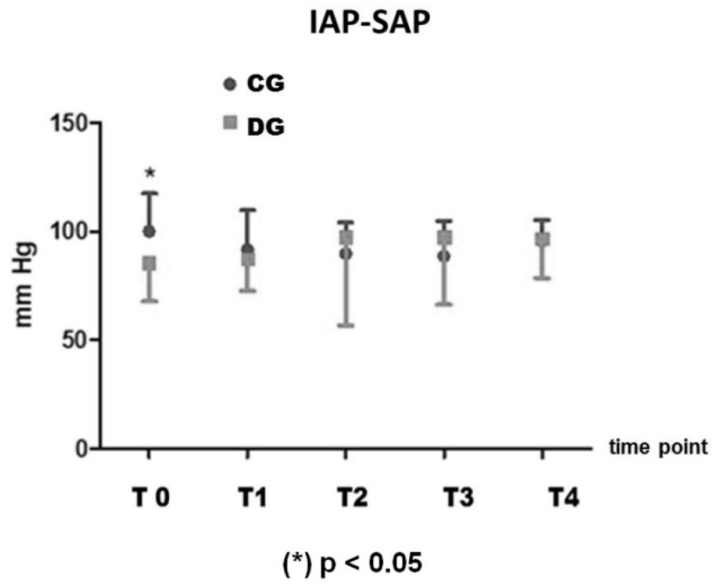

Fig.2. Graphical representation of mean and standard deviation values of the mean arterial pressure (MAP) measured invasively (invasive arterial pressure - IAP) in animals from the control group (CG) and the diabetic group (DG) at different time-points.

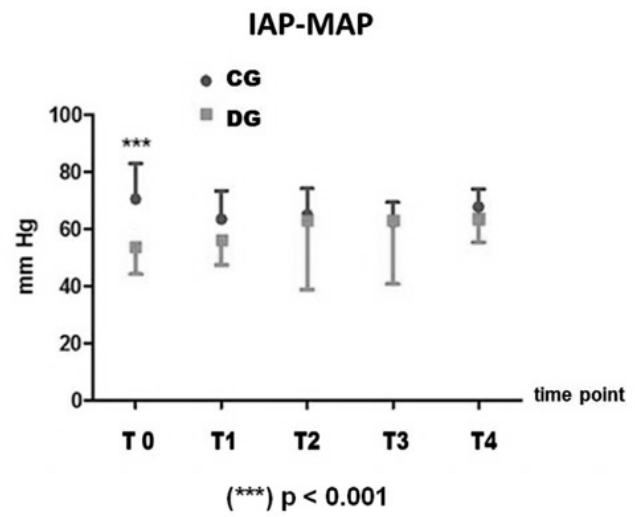

Fig.3. Graphical representation of mean and standard deviation values of the mean arterial pressure (MAP) measured invasively (invasive arterial pressure - IAP) in animals from the control group (CG) and the diabetic group (DG) at different time-points.

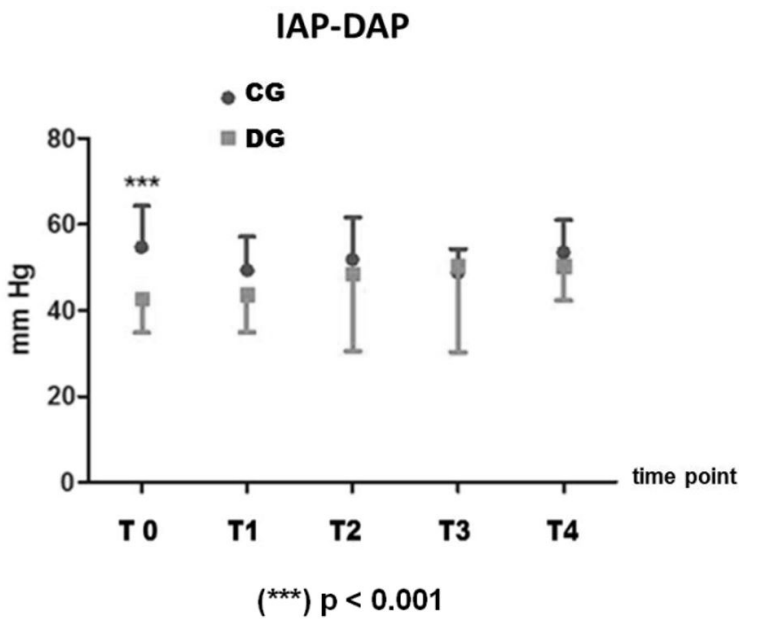

Fig.4. Graphical representation of mean and standard deviation values of the diastolic arterial pressure (DAP) measured invasively (invasive arterial pressure - IAP) in animals from the control group (CG) and the diabetic group (DG) at different time-points

\section{DISCUSSION}

The mean age of the diabetic dogs (approximately 10 years) was similar to that described in the literature, which also demonstrates the greater occurrence of diabetes in middle-aged to elderly dogs (Feldman \& Nelson 2004, Fall et al. 2007). A previous study performed with dogs also subjected to cataract surgery showed that diabetic patients were older (mean 9.9years) compared with nondiabetic patients (mean 7.54 years) (Bagley \& Lavach 1994). There are several causes of cataract formation in dogs. In addition to diabetes mellitus, cataracts may be hereditary and result from trauma, intraocular inflammation, and nutrition, which may affect dogs of all ages and explains the higher incidence of young dogs in the control group (Lim et al. 2011).

Regarding gender distribution, there was no difference between the number of males and females between the groups. In previous studies, diabetes has been shown to be more prevalent in females, especially during the diestrus phase in which the level of progesterone is increased (Feldman \& Nelson 2004, Fall et al. 2007). There is a possibility of remission of diabetes if bitches undergo ovariohysterectomy as soon as possible; some studies have shown remission rates between 5 and $58 \%$ (Feldman \& Nelson 2004, Fall et al. 2008, 2010). In the present study, all diabetic females were previously subjected to ovariohysterectomy, which is indicated for reducing insulin resistance due to decreased progesterone concentration and results in better glycemic control (Selman et al. 1994).

The objective of the therapy in diabetic patients is remission of clinical signs and return to a normal life. Even dogs with compensated diabetes have high blood glucose levels compared with healthy animals and are more prone to the formation of ketoacids and metabolic acidosis (Fleeman \& Rand 2001). Similarly to previous data, in the present study, diabetic patients also exhibited significantly higher glucose levels compared with the control group in most of the perioperative period. However, at initial time (T0), some diabetic patients presented hypoglycemia due to insulin administration at fasting before surgery.

Serum fructosamine is formed through non-enzymatic irreversible reactions between glucose and serum proteins. Fructosamine concentration directly depends on the blood protein concentrations and their composition and on the plasma glucose concentration. In dogs, because the average life of albumin is 8.2 days, the fructosamine concentration reflects glycaemic status over the previous 1 to 3 weeks (Kawamoto et al. 1992). In the present study, all the diabetic patients exhibited fructosamine levels above $300 \mu \mathrm{mol}$, and $53 \%$ of the diabetic patients showed values above $500 \mu \mathrm{mol}$. A study compared fructosamine values in diabetic and healthy dogs, and $41 \%$ of the diabetic animals showed inadequate glycemic control with values above $300 \mu \mathrm{mol}$; however, fructosamine values ranged between 140 and $151 \mu \mathrm{mol}$ in healthy animals (Sako et al. 2008).

Serum fructosamine values in dogs can be changed by other factors as well, such as hypoproteinemia, azotemia, and hyperlipidemia (Reusch \& Haberer 2001).

Hyperlipidemia is another common problem in diabetic dogs (Plummer et al. 2007). The increases in triglycerides and cholesterol levels in diabetic dogs occur due to decreased lipoprotein metabolism secondary to decreased insulin levels (Hess et al. 2003, Durocher et al. 2008). Animals from the 
DG showed significantly higher cholesterol levels. However, triglyceride levels did not show significant differences, contrary to the findings of Durocher et al. (2008), who found that diabetic patients exhibited higher triglyceride concentrations. This difference may not have been significant because both groups contained obese patients. A study performed with obese dogs report that animals with high body condition score have severe hyperlipidemia (Brunetto et al. 2011).

Dogs in this study developed mild acidemia ( $\mathrm{pH}$ around 7.3 at the end of the surgical procedure in both groups), but no signs of metabolic acidosis. Anion gap and blood bicarbonate values remained within normal ranges throughout the experimental period. Therefore, acid-base balance seems to be preserved in dogs with compensated DM. Similar normal blood bicarbonate levels and anion gap values have been previously demonstrated in healthy and insulin-treated diabetic dogs (Durocher et al. 2008). Anesthesia is thought to decrease blood bicarbonate levels and anion gap; therefore, anesthetized patients may develop acidemia in response to transanesthetic hypovolemia, decreased cardiac output, hypotension-related low tissue perfusion and hypothermia.

Regarding the physiological variables analyzed during surgery, arterial hypotension was the most common complication, and $80 \%$ of the diabetic dogs $(n=12)$ and $33 \%$ of the animals from the control group $(n=5)$ exhibited invasive mean arterial pressure below $60 \mathrm{mmHg}$ in the moments after induction. In a previous study, only $21 \%$ of the diabetic dogs showed hypotension during surgery (Kronen et al. 2001). A retrospective study reported hypotension in $71 \%$ of diabetic dogs and in $63 \%$ of non-diabetic animals (Oliver et al. 2010). The difference between the studies may be related to the measurement methods and to the definition of hypotension. In the present study, only the invasive method was used because it is considered to be more accurate, the surgical time was standardized, and only unilateral phacoemulsification was performed.

Management of hypotension during anesthesia includes assessment and correction o ferrors in anesthetic depth, arrhythmias and obvious or potential volume deficits. If hypotension persists despite these steps, then administration of inotropic drugs may be necessary to maintain blood pressure (Chen et al. 2007).

The use of acepromazine as premedication aimed to reduce the stress of the animals and to potentiate the drugs that were administered later. It is known that although the use of acepromazine has these beneficial effects, it increases the hypotensive effect of inhalational anesthetics, such as isoflurane, due to blockade of alpha-adrenergic receptors and depression of the vasomotor center (Monteiro et al. 2007, Sinclair \& Dyson 2012). However, there is no evidence that acepromazine causes clinically significant hypotension in normovolemic dogs (Boström et al. 2003).

Propofol and isoflurane are used extensively for induction and maintenance of anesthesia in dogs sedated with acepromazine and, of ten both are each associated with a degree of cardiovascular depression.

In order to minimize cardiorespiratory effects in both groups, dose of propofol to promote orotracheal intubation was similar the doses recommended in the literature ( 3 a $5 \mathrm{mg} / \mathrm{kg}$ ) (Glowaski \& Wetmore 1999).
Likewise, the concentration of isoflurane used for the maintenance of anesthesia was lower than 1 CAM (1 to $1.3 \%$ ), and in the diabetic dogs, it was 30\% lower during induction and after 30 minutes. The increased incidence of hypotension in diabetic dogs may be related to their hyperglycemic state due to osmotic diuresis, dehydration, and hypovolemia and may predispose the animals to hypotension during anesthesia (Kronen et al. 2001). However, the decrease in the inspired concentration of the inhalational anesthetic and the fluid administration were sufficient to normalize the blood pressure in animals from the control group, which did not occur with diabetic dogs. During episodes of hypotension, all diabetic animals required vasoactive drugs. However, the administration of ephedrine was not effective for maintaining normotension in all animals. Ephedrine, which is an agonist of $\alpha$ and $\beta$ receptors, determines the presynaptic release of norepinephrine by sympathetic neurons in peripheral nerve endings to the extracellular fluid. Ephedrine also stimulates the cardiac rate and output, variably increases the peripheral resistance, and increases the blood pressure (Westfall \& Westfall 2012). Because no positive results were observed, norepinephrine was administered, which is an endogenous catecholamine with potent $\alpha$-agonist effect. Norepinephrine promotes increased blood pressure by increasing peripheral resistance, and the compensatory vagal reflex activity decreases the heart rate (Westfall \& Westfall 2012). In the present study, four animals that received norepinephrine infusion showed improved hypotension. Thus, there is evidence that patients with cardiovascular autonomic neuropathy subjected to general anesthesia demonstrate a higher incidence of hypotension. Because these patients have low plasma catecholamines levels, norepinephrine infusion may have a beneficial effect.

In addition to the previously mentioned factors, the fact that diabetic patients were older compared with the control group should be considered. Previous studies have shown that elderly patients exhibit changes in autonomic responses that control the heart rate and blood pressure and may not be able to compensate the hypotension caused by vasodilators such as acepromazine (Hughes 2008).

However, in humans, the most common cause of hypotension during general anesthesia occurs in diabetic patients with cardiovascular autonomic neuropathy. This occurs when peripheral autonomic nerve fibers (sympathetic and parasympathetic) of the cardiovascular system are injured, and these abnormalities are associated with heart rate control and vascular dynamics (Latson et al. 1994). Patients with this dysfunction have greater difficulty compensating the effects of anesthetic induction on venous return, vascular tone, and myocardial contractility (Latson et al. 1994). Human patients who demonstrated autonomic dysfunction in the preoperative period as shown by the analysis of heart rate variability exhibited a higher incidence of hypotension and bradycardia after induction of general anesthesia (Huang et al. 2006, Hanss et al. 2008). There is limited evidence of the existence of this neuropathy in dogs. A recent study assessed the presence of cardiac autonomic neuropathy in dogs with diabetes mellitus and found decreased heart rate variability and plasma norepinephrine concentration, which are variables commonly used in the diagnosis of this type of neuropathy compared with healthy animals (Pirintr et al. 2012). Diabetic patients were also divided into two groups according to 
glycemic control, demonstrating that patients with higher fructosamine and glucose levels exhibited higher autonomic changes (Pirintr et al. 2012). Thus, some specific aspects of the cardiovascular response of the diabetic patient need to be investigated.

\section{CONCLUSIONS}

In summary, a significant proportion of diabetic dogs are subjected to ophthalmic surgery, and they are more susceptible to anesthetic complications.

Hydration and blood glucose levels should be properly assessed and controlled before surgery.

In the present study, the only complication found was hypotension, especially after anesthetic induction, being observed in $80 \%$ of the diabetic animals.

Regarding hemodynamic changes, diabetic patients subjected to general anesthesia were more likely to exhibit hypotension which may be due to the response of older animals to the drugs used; however, this change deserves further investigation.

Acknowledgements. - The authors wish to thank the Fundação de Amparo a Pesquisa do Estado de São Paulo (FAPESP) for financial support (process no. 2012/0018-4).

\section{REFERENCES}

Bagley 2nd L.H. \& Lavach J.D. 1994. Comparison of postoperative phacoemulsification results in dogs with and without diabetes mellitus: 153 cases (1991-1992). J. Am. Vet. Med. Assoc. 205(8):1165-1169. <PMid:7890577>

Beam S., Correa M.T. \& Davidson M.G. 1999. A retrospective-cohort study on the development of cataracts in dogs with diabetes mellitus: 200 cases. Vet. Ophthalmol.2(3):169-172.<http://dx.doi.org/10.1046/j.1463-5224.1999.00073. $\mathrm{x}><$ PMid:11397260>

Boström I., Nyman G., Kampa N., Häggström J. \& Lord P. 2003. Effects of acepromazine on renal function in anesthetized dogs. Am. J. Vet. Res. 64(5):590598. <http://dx.doi.org/10.2460/ajvr.2003.64.590><PMid:12755300>

Brunetto M.A., Nogueira S., Sá F.C., Peixoto M., Vasconcellos R.S., Ferraudo A.J. \& Carciofi A.C. 2011. Correspondência entre obesidade e hiperlipidemia em cães. Ciência Rural 41(2):266-271. <http://dx.doi.org/10.1590/ S0103-84782011005000004>

Chen H.C., Sinclair M.D. \& Dyson D.H. 2007. Use of ephedrine and dopamine in dogs for the management of hypotension in routine clinical cases under isoflurane anesthesia. Vet. Anaesth. Analg. 34(5):301-311.<http://dx.doi. org/10.1111/j.1467-2995.2006.00327.x><PMid:17532806>

Durocher L.L., Hinchcliff K.W., Dibartola S.P. \& Johnson S.E. 2008. Acid-base and hormonal abnormalities in dogs with naturally occurring diabetes mellitus. J. Am. Vet. Med. Assoc. 232(9):1310-1320. <http://dx.doi. org/10.2460/javma.232.9.1310> <PMid:18447775>

Fall T., Hamlin H.H., Hedhammar A., Kämpe O. \& Egenvall A. 2007. Diabetes mellitus in a population of 180,000 insured dogs: incidence, survival, and breed distribution. J. Vet. Intern. Med. 21(6):1209-1216. <http://dx.doi. org/10.1111/j.1939-1676.2007.tb01940.x><PMid:18196728>

Fall T., Johansson Kreuger S., Juberget A., Bergström A. \& Hedhammar A. 2008. Gestational diabetes mellitus in 13 dogs. J. Vet. Intern. Med. 22(6):1296-1300. <http://dx.doi.org/10.1111/j.1939-1676.2008.0199.x><PMid:18976285>

Fall T., Hedhammar A., Wallberg A., Fall N., Ahlgren K.M., Hamlin H.H., LindbladToh K., Andersson G. \& Kämpe 0. 2010. Diabetes mellitus in Elkhounds is associated with diestrus and pregnancy. J. Vet. Intern. Med. 24(6):1322-1328. <http://dx.doi.org/10.1111/j.1939-1676.2010.0630.x><PMid:21054539>
Feldman E.C. \& Nelson R.W. 2004. Canine diabetes mellitus, p.580-615. In: Ibid. (Eds), Canine and Feline Endocrinology and Reproduction. 3rd ed. Saunders, Philadelphia.

Fleeman L.M. \& Rand J.S. 2001. Management of canine diabetes. Vet. Clin. N. Am., Small Anim. Pract. 31(5):855-880. <http://dx.doi.org/10.1016/ S0195-5616(01)50003-0><PMid:11570130>

Glowaski M.M. \& Wetmore L.A. 1999. Propofol: application in veterinary sedation and anesthesia. Clin. Tech. Small Anim. Pract. 14(1):1-9. <http:// dx.doi.org/10.1016/S1096-2867(99)80021-8><PMid:10193040>

Hanss R., Renner J., Ilies C., Moikow L., Buell O., Steinfath M., Scholz J. \& Bein B. 2008. Does heart rate variability predict hypotension and bradycardia after induction of general anaesthesia in high risk cardiovascular patients? Anaesthesia 63(2):129-135. <http://dx.doi.org/10.1111/j.1365-2044.2007.05321.x> $<$ PMid:18211442>

Haskins S.C. 2003. Operating room emergencies, p.2516-2532. In: Slatter D. H. (Ed.), Textbook of Small Animal Surgery. 3rd ed. Saunders, Philadelphia.

Hess R.S., Kass P.H. \& Winkle T.J. 2003. Association between diabetes mellitus, hypothyroidism or hyperadrenocorticism, and atherosclerosis in dogs. J. Vet. Intern. Med. 17(4):489-494.<http://dx.doi.org/10.1111/j.1939-1676.2003. tb02469.x><PMid:12892299>

Huang C.J., Kuok C.H., Kuo T.B., Hsu Y.W. \& Tsai P.S. 2006. Pre-operative measurement of heart rate variability predicts hypotension during general anesthesia. Acta Anaesthesiol. Scand. 50(5):542-548. <http://dx.doi. org/10.1111/j.1399-6576.2006.001016.x><PMid:16643221>

Hughes J. 2008. Anaesthesia for the geriatric dog and cat. Irish Vet. J. 61(6):380-387. <PMid:21851715>

Kawamoto M., Kaneko J.J., Heusner A.A., Feldman E.C. \& Koizumi I. 1992. Relation of fructosamine to serum protein, albumin and glucose concentrations in healthy and diabetic dogs. Am. J. Vet. Res. 53(5):851-855. <PMid:1524315>

Kronen P., Moon-Massat P., Ludders J., Gleed R., Kern T., Randolph J. \& Erb H.N. 2001. Comparison of two insulin protocols for diabetic dogs undergoing cataract surgery. Vet. Anesth. Analg. 28(3):146-155. <http://dx.doi. org/10.1046/j.1467-2987.2001.00053.x> <PMid:28404445>

Latson T.W., Ashmore T.H., Reinhart D.J., Klein K.W. \& Giesecke A.H. 1994. Autonomic reflex dysfunction in patients presenting for elective surgery is associated with hypotension after anesthesia induction. Anesthesiology 80(2):326-337. <http://dx.doi.org/10.1097/00000542-19940200000013><PMid:8311315>

Lim C.C., Bakker S.C., Waldner C.L., Sandmeyer L.S. \& Grahn B.H. 2011. Cataracts in 44 dogs (77 eyes): a comparison of outcomes for no treatment, topical medical management, or phacoemulsification with intraocular lens implantation. Can. Vet. J. 52(3):283-288. <PMid:21629421>

Monteiro E.R., Teixeira Neto F.J., Castro V.B. \& Campagnol D. 2007. Effects of acepromazine on the cardiovascular actions of dopamine in anesthetized dogs. Vet. Anesth. Analg. 34(5):312-321. <http://dx.doi. org/10.1111/j.1467-2995.2006.00328.x><PMid:17686118>

Oliver J.A.C., Clark L., Corletto F. \& Gould D.J. 2010. A comparison of anesthetic complications between diabetic and nondiabetic dogs undergoing phacoemulsification cataract surgery: a retrospective study. Vet. Ophthalmol. 13(4):244-250. <http://dx.doi.org/10.1111/j.1463-5224.2010.00793.x> $<$ PMid:20618803>

Pirintr P., Chansaisakorn W., Trisiriroj M., Kalandakanond-Thongsong S. \& Buranakarl C. 2012. Heart rate variability and plasma norepinephrine concentration in diabetic dogs at rest. Vet. Res. Commun. 36(4):207-214. <http://dx.doi.org/10.1007/s11259-012-9531-0> <PMid:22855304>

Plummer C.E., Specht A. \& Gelatt K.N. 2007. Ocular manifestations of endocrine disease. Compendium Continuing Educ. Vet. 29(12):733-743. <PMid:18225637>

Reusch C.E. \& Haberer B. 2001. Evaluation of fructosamine in dogs and cats with hypo-or hyperproteinaemia, azotaemia, hyperlipidaemia and 
hyperbilirubinaemia. Vet. Rec. 148(12):370-376.<http://dx.doi.org/10.1136/ vr.148.12.370 > <Pid:11321552>

Sako T., Mori A., Lee P., Takahashi T., Izawa T., Karasawa S., Furuuchi M., Azakami D., Mizukoshi M., Mizutani H., Kiyosawa Y. \& Arai T. 2008. Diagnostic significance of serum glycated albumin in diabetic dogs. J. Vet. Diagn. Invest. 20(5):634-638. <http://dx.doi.org/10.1177/104063870802000517> $<$ PMid:18776099>

Selman P.J., Mol J.A., Rutteman G.R., van Garderen E. \& Rijnberk A. 1994. Progestin-induced growth hormone excess in the dog originates in the mammary gland. Endocrinology 134(1):287-292. <http://dx.doi. org/10.1210/endo.134.1.7506206><PMid:7506206>
Sinclair M.D. \& Dyson D.H. 2012. The impact of acepromazine on the efficacy of crystalloid, dextran or ephedrine treatment in hypotensive dogs under isoflurane anesthesia. Vet. Anesth. Analg. 39(6):563-573. <http://dx.doi. org/10.1111/j.1467-2995.2012.00766.x><PMid:23035903>

Tanifuji Y. \& Eger 2nd E.L. 1976. Effect of arterial hypotension on anaesthetic requirement in dogs. Brit. J. Anaesth. 48(10):947-952. <http://dx.doi. org/10.1093/bja/48.10.947> <PMid:990148>

Westfall T.C. \& Westfall D.P. 2012. Agonistas e antagonistas adrenérgicos, p.277-333. In: Brunton L. L., Chabner B. A. \& Knollmann B. C. (Eds), As Bases Farmacológicas da Terapêutica de Goodman e Gilman. 12 $2^{\underline{a}}$ ed. AMGH, São Paulo. 